\title{
INTERNAL MARKETING STRATEGY: FOCUSING ON STAFF ORIENTATION IN HEALTH CARE IN SOUTH AFRICA
}

\author{
De Jager JW and Swanepoel S, Tshwane University of Technology, Pretoria, South Africa
}

Purpose: The purpose of the paper is to determine the levels of satisfaction in respect of pre identified internal marketingrelated variables in a large provincial hospital in South Africa.

Problem investigated: Low job satisfaction is often cited as a major cause of high turnover among health care providers worldwide. Likewise the Public Health Care Industry in South Africa is facing complex employee retention issues. In determining the reasons for high turnover an interest in evaluating employee satisfaction among health care providers has increased. Measuring components of job satisfaction will assist not only the health care organisations' management to understand hospital culture, but also to compile an effective internal marketing plan and strategy.

Design/Methodology/Approach: A staff satisfaction survey was conducted amongst staff members at a provincial hospital in the Tshwane region, South Africa. Attitudes of staff on pre-identified staff satisfaction variables were assessed. These variables were employed to implement an internal marketing strategy. A list of variables was formulated after an extensive literature study had been conducted. A total of 416 staff members voluntarily completed a self-administered questionnaire. A five-point Likert type scale was used to measure the levels of satisfaction on staff-related issues, with a view to addressing issues in the internal marketing strategy.

Findings: It was evident that the management principles currently employed by the management team were a cause for concern among staff members. Based on the analysis that identified the satisfaction variables best it was clear that management should take immediate steps to address the following issues:

- Clarification of hospital goalslobjectives;

- Understanding the goals of the respective departments;

- The functioning of the Human resource department;

- Functioning of the overall hospital management; and

Implications: This paper aims to present a comprehensive framework for Provincial Hospital Management to prioritise important staff related issues in order to satisfy their needs. The recommendations of this study need to be applied if acceptable health care is to be provided.

Originality/Value: This study challenges existing internal marketing studies on health care services. Its significance lies in an attempt to establish the needs of diversified health care staff in a health care setting. It offers uniquely South African internal marketing framework that focuses on similarities and differences between medical and nursing staff in a Gauteng public hospital.

Key words and phrases: Service quality, health care, provincial hospitals, internal marketing, staff satisfaction.

\section{INTRODUCTION}

Low job satisfaction is a major cause of high turnover among health care providers (Krueger, Brazil, Lohfeld, Edward, Lewis \& Tjam, 2002; Costello, 2001 and Nobile \& McCormick, 2008). Job satisfaction that affects the quality of service and organisational commitment may be a contributing factor in the shortage of health care providers. These observations led to an increased interest in assessing job satisfaction levels among health care providers. 
The Public Health Care Industry in South Africa is faced with complex employee retention issues, therefore health care providers have realised the importance of ascertaining the level of employee satisfaction. Measuring the levels of job satisfaction not only assist the health care organisational leadership in understanding the hospital culture, but also in compiling an effective internal marketing plan and strategy.

Almost every service organization declares its commitment to service quality especially where competition is fierce. Evidence indicates that almost without any exception, substantial gaps exist between patients' expectations and their perceptions (Hill \& McCrory, 1997; Friedenberg, 1997; Dyck, 1996; Donabedian, 1988; Car Hill, 1992; Busch, 2000; Simonet, 2005 and Kollberg, Dahlgaard \& Brehmer, Sajid, 2007). Czaplewski, Furguson and Milliman (2001) ascribe this phenomenon to the lack of commitment and skills of frontline employees who interact with customers. The missing element is internal marketing. This involves treating frontline, contact employees as internal customers to ensure that these employees provide excellent service to the end customer. Internal marketing is viewed by various authors as an important means to obtain, develop, motivate and retain skilled, energized employees who in turn will provide high quality service (Czaplewski, Furguson \& Milliman, 2001; Cravens \& Piercy, 2003; Kotler \& Armstrong, 1993; Strydom, 2004; Du Plessis, Jooste \& Strydom, 2005 and Gounaris, 2008). The primary objective of the paper is to determine the levels of satisfaction according to pre-identified staff satisfaction variables, in a large hospital in South Africa. This is done in order to introduce an internal marketing strategy to the institution.

A brief description of internal marketing, some definitions of internal marketing, its application and effectiveness within an organisation is provided. Following the major factors influencing respondents satisfaction levels are discussed and then the research methodology, results and findings are provided.

\section{INTERNAL MARKETING*}

Kotler and Andreasen (1996:379-380) point out that service encounters are often tainted by unresponsive actions of service providers such as front line staff. These staff members do not realise that they have to meet customers' needs and wants. Service providers too often place their own and their organisation's needs first. The solution to this problem could lie in internal marketing. Strydom $(2004: 15,272)$ defines internal marketing as a company's efforts to communicate with and motivate employees to strive for improvement in customer satisfaction. This includes training of employees as well as providing them with the relevant tools and skills to perform their jobs optimally so that the customer is provided with satisfactory service. Cahill (1996:5) and Gounaris (2008:69) point out that the most important aspect of internal marketing is effective communication with employees. Employees need to be trained to do their jobs effectively and efficiently, to ensure that external customers and internal customers are well served by the organisation. In the following section the application of internal marketing in an organisation will be discussed.

\section{DEFINITION OF INTERNAL MARKETING}

Berry and Parasuraman (1991:151) defines internal marketing as attracting, developing, motivating and retaining qualified employees through job - products that satisfy their needs. Internal marketing is the philosophy of treating employees as customer-indeed, "wooing" employees... and is the strategy of shaping job-products to fit human needs.

Grönroos (1981a) as cited by Cahill (1996) defines internal marketing as "Selling the firm to its employees" who are treated as internal customers. The result of higher employee satisfaction will make it possible to develop a more customer focused and market oriented firm.

Kotler and Armstrong (1993:499) refer to internal marketing as motivating its employees to work as a team to provide top quality service. Internal marketing means that the service firm must effectively train and motivate its customers-contact employees and all the supporting service people to work as a team to 
provide customer satisfaction. For a firm to deliver consistently high service quality, everyone should practice a customer orientation. It is not enough to have a marketing department doing traditional marketing while the rest of the company goes its own way. Internal marketing should precede external marketing that means that the customer cannot be serviced unless the staff members are ready for it.

It is clear that such a proliferation of definitions proves the growing interest amongst service providers to get employees to adopt the marketing concept of customer orientation and to become part of the organizations team (Joseph, 1996:54). For the purpose of the study, internal marketing can thus be regarded as a package of employee related issues that should be satisfied and monitored as prerequisite for satisfying (external) customer's needs with their products and service offerings. This employee related package will consequently be investigated.

\section{APPLICATION OF INTERNAL MARKETING IN AN ORGANISATION}

The objective of internal marketing, within relationship marketing, according to Du Plessis, Jooste and Strydom (2005:299) is to create relationships between management and employees, and between functions while management has the responsibility to train and motivate employees, it also has persuaded them to support the marketing strategy actively. This implies that front line staff, who interact with external customers, should manage the service encounter well and show greater independence. It is crucial that contact staff is conversant with an organisation's mission, goals, strategies and organisational processes. It is equally important for support staff to enable them to handle internal customer relationships successfully. Employees who influence external service perceptions are often among the lower ranks in the company. In order to provide superior service quality, management should embark on an internal marketing strategy. The firm's own employees need to be made aware of the fact that they work for a superior company of which they can be proud (Soloman \& Stuart, 2003:327). If the service provider does not believe in the job and the company, this attitude will soon be perceived by the customer.

\section{ASPECTS OF AN EFFECTIVE INTERNAL MARKETING STRATEGY}

Before implementing an effective internal marketing strategy, it is important to assess the employees' level of satisfaction on job-related issues. Caruana and Calleya (1998:109) and Gounaris (2008:74) relate the importance of customer satisfaction to the success of a service firm. One of the consequences of internal marketing is to increase the organisational commitment of employees. This in turn leads to increased job satisfaction, increased job performance and a lower turnover of staff. However, Gibson, Ivancevich, Donelly and Konopaske (2003:105) indicate that these factors are rarely instrumental in bringing about high job attitudes and do not focus on the job itself. They focus on the characteristics of the context in which the job is done. These include: working conditions, interpersonal relationships, supervision, company policies, administration of these policies, effects on the employees' personal life, job security and salary. Job satisfaction, like any other attitude, generally develops over a period of time, as an employee gains more and more information about his organisation. However, it is dynamic as the level can decline even more rapidly than it increased. Therefore, managers need to pay attention to employees' attitudes on a weekly, monthly and annual basis (Bergh \& Theron, 1999:191, Gounaris, 2008:74). Although a variety of aspects influence's a person's levels of satisfaction, the following major factors were identified using the data collection instrument. Evidence of these variables are also to be found in various publications (Ahmed \& Rafic, 2002:9). In this section a distinction between management, ability to perform, synergistic operational functions, organizational citizenship and customer service/relations.

\section{Management}

Bunz and Maes (1998:164) and De Nobile and McCormick (2008:136) point out that good managementemployee relations are paramount in service organisations. According to Kotler and Clarke (1987:154) the management team of health care organisations creates the climate for an effective organisation. The 
team should through their actions and words create a climate conducive to work. Aspects that should be addressed are setting of goals and objectives, labour related issues and personnel management. These aspects that were included in the study, were used to gauge staff satisfaction. According to Robbins and Coultar (1996), and Zeffane and Zarooni (2008:195) employees are more satisfied when their managers are good leaders. This includes motivating employees to do a good job, striving for excellence or just taking action. Individuals at all levels of the organization want their achievements on the job to be acknowledged. Their successes don't have to be spectacular before recognition is given, but management's praise needs to be sincere (De Jager \& Swanepoel, 2005:149). Management should make time to acknowledge the good work of employees immediately by publicly thanking them for handling a situation particularly well or by writing a note expressing appreciation (Robbins \& Coultar, 1996).

\section{Ability to Perform}

One premise inherent in Herzberg's theory is that most individuals do want to do a good job. In order to manage employees effectively, they should be placed in positions in which they can use their talents thereby ensuring that they are not set up for failure (Nel, Van Dyk, Haasbroek, Schultz, Sano \& Werner, 2004:262). Clear, achievable goals and standards should be set for each position.

Employees are aware what those goals and standards are. This will contribute to the capabilities of employees to perform. In addition individuals should receive regular, timely feedback on how they are doing and should feel that they are being adequately challenged in their jobs. Be careful, however, not to overload individuals with challenges that are too difficult or impossible, as that can be paralyzing (Muchinsky, 1993:289). According to Hellriegel, Slocum and Woodman (2001:52), employees will be more motivated to perform their jobs well if they have ownership of their work. This "ownership" requires giving employees enough freedom and power to carry out their tasks so that they feel they "own" the result (Bunz \& Maes, 1998:165). As individuals mature in their jobs, opportunities should be provided for added responsibility. Instead this should be challenging and meaningful work. Perhaps the employee should be given greater freedom and authority to make decisions. Sufficient training programmes should be in place to equip health care workers with the necessary skills to perform their duties as efficiently as possible. In many cases people's lives are at stake (Kotler \& Clarke, 1987 and De Jager \& Swanepoel, 2005:149).

\section{Synergistic Operational Functions}

Various operational functions are provided by health care organisations. The research instrument focused on the opinion of the employees regarding the number of facilities in their distinctive sections. Grönroos (1978:6) suggests that internal marketing is a holistic process, which integrates the multiple functions of the firm, by ensuring that employees understand all aspects of business operations and are motivated to act in a service-oriented manner. Grönroos concludes that an important factor influencing the internal marketing concept is that building stronger relations with customers, it is only feasible, if preceded by attention to integration of service provision processes across the entire organisation. Working conditions and facilities must be conducive to assisting workers to do their jobs well. These include safety and comfort, a clean environment, relatively modern facilities and adequate equipment (Bergh \& Theron, 1999:191). Research mentioned by Robbins (2003) indicates that working conditions and facilities are important factors that impact on the levels of job satisfaction of employees.

\section{Organisational Citizenship}

Organisational citizenship can be defined as discretionary behaviour that is not part of an employee's formal job description. However, this promotes the effective functioning of the organisation. These behaviours are a matter of personal choice, therefore the omission is not generally understood as being a punishable offence. Organisational Citizenship Behaviours (OCBs) are deemed to have a significant impact on the effectiveness and efficiency of work teams and organizations, therefore they contribute to 
the overall productivity of the organization. They are often described as behaviours that "go above and beyond the call of duty". Not surprisingly, OCBs are considered to arise, at least in part, from intrinsic motivation including a positive state of mind and the need for affiliation or a sense of achievement (Robbins \& Judge, 2007:122 and Nelson \& Quick, 2003:123).

The idea that effective organisations can be created by focusing on performance while ignoring the role of emotions, is based on the false premise that emotions can be ignored in the workplace. Positive relationships and a sense of community engender positive emotions. The importance of human need, capacity and potential must be evident when trying to create positive organisations that succeed. At the same time it is essential to foster the health and well-being of those who work in them. Positive emotions encourage organisational citizenship.

Those employees who put in effort beyond that which is prescribed are highly valued by management. This phenomenon is critical for organisational efficacy because managers cannot possibly foresee all contingencies or fully anticipate the activities that they may desire or need employees to perform (Organ, 1988 and Zaffane \& Zarooni, 2008). Work behaviour, that goes beyond the reach of organisational measures of job performance, almost certainly ensures long-term organisational success (Van Dyne, Graham \& Dienesch, 1994). These actions are purported to improve organisational efficiency, efficacy and adaptability (Organ 1988). Going beyond what is required without expecting to be rewarded, is referred to in this study as Organisational Citizenship Behaviour (OCB).

\section{Customer Service/Relations}

According to Czaplewski, Ferguson and Milliman (2001) good internal marketing involves giving service employees the opportunity to create value for their customers and to achieve recognition for themselves. An effective internal marketing strategy should empower employees to make their own judgements on and decisions about their role in service delivery. Most people believe that work should not simply be an economic necessity, but that it should also provide a means for enhancing their dignity through greater involvement in the workplace (McCormick \& Ilgen, 1992:309).

Schultz and Schultz (1994) state that if an employee realises that he/she can influence the working environment, whether it be policy changes or working conditions, this will result in feelings of personal mastery. In turn it is a reflection of their orientation towards their work as well as relations with customers.

The intensity of an individual's psychological identification with the job will influence the levels of job satisfaction and loyalty towards the organisation. It is imperative that employees develop a work personality. This refers to valuing work as a necessary, worthwhile life interest through which to achieve things for themselves. Individuals with high job involvement care about their work and strongly identify with it and creating and maintaining good customer relationships inevitably follow (Bergh \& Theron, 1999:192).

In the next section the objectives of the study and the research methodology is dealt with.

\section{OBJECTIVE OF THE STUDY}

The primary objective of the study is to determine the levels of satisfaction in respect of pre- identified internal marketing-related variables in a large provincial hospital in South Africa.

\section{RESEARCH METHODOLOGY}

The research methodology, including conceptualising the purpose of the investigation, the research hypotheses, sample framework, the measuring instrument and reliability measures will consequently be discussed. 


\section{Conceptualising the Purpose of the Investigation}

In order to achieve the primary objective of the research a factor structure was determined of the staff satisfaction variables as evaluated by the staff.

The following secondary objectives were formulated:

- To evaluate the expressed levels of staff satisfaction of medical staff (doctors) and nursing staff with these identified factors;

- To determine the existence of significant differences in staff satisfaction variables between medical and nursing staff members in respect of staff satisfaction variables,

- To determine which staff satisfaction variables describe satisfaction best; and

- To determine the existence of significant differences in staff satisfaction between medical and nursing staff members regarding those staff satisfaction variables that describe satisfaction accurately.

\section{Research Hypotheses}

From the staff satisfaction variables the following hypotheses were formulated:

- Ho: No significant differences exist between staff satisfaction evaluations of medical and nursing staff samples.

- Ha: Significant differences exist between staff satisfaction evaluations of medical staff and the nursing staff samples.

\section{The Sample Framework}

A staff satisfaction survey was conducted amongst staff members at a provincial hospital in the Tshwane region, South Africa. The attitudes of the staff were tested regarding certain pre-identified staff satisfaction variables. These variables were identified in order to implement an internal marketing strategy. A list of variables was generated after an extensive literature study had been conducted. Focus groups consisting of staff members employed by the hospital were identified as well. The final questionnaire was approved by the hospital's management team and the researchers. A total of 416 out of approximately 3000 staff members voluntarily completed a self-administered questionnaire. The questionnaires were left in pre-identified sealed boxes in order to protect each staff member's identity.

Almost $60 \%$ of the employees are employed in a medical or nursing capacity. Ninety percent of the medical staff and $85 \%$ of the nursing staff members respectively have been employed for more than 2 years at the hospital. Sixteen percent of the medical staff is employed in a management position as compared to $12 \%$ of the nursing staff members. Sixty-six percent of the medical staff are employed in an operational capacity, while $55 \%$ of the other staff members are employed in an operational capacity.

\section{The Measuring Instrument and Reliability Measures}

A five-point Likert type scale was used to measure the levels of satisfaction with regard to staff related matters as indicated by a number of predetermined items that comprised the questionnaire. Respondents were asked to indicate their levels of satisfaction on the following scale in which: $1=$ Very poor, $2=$ Poor, $3=$ Average, $4=$ Good and $5=$ Excellent

An item analysis was carried out to test the reliability of the questionnaire and an overall Cronbach coefficient Alpha of 0,91 was measured. A two sample t test was conducted to test the null hypothesis 
and the alternative hypothesis that no significant differences exists between the levels of satisfaction of the two groups and on the other hand that significant differences do exist between the groups (medical staff and nursing staff).

An explanation of the data analysis and findings are consequently provided.

\section{DATA ANALYSIS AND FINDINGS}

The data analysis, including determining the factor structure is discussed in the following section.

\section{Determining the Factor Structure of the After-Service Evaluation}

A factor structure was developed for the staff satisfaction evaluation using an orthogonal rotation method. This was achieved through identifying those items that correlate highly with several of the items in the questionnaire, but are relatively independent of one another. Only data items with loadings higher than 0,50 were selected. In addition only factors with an eigenvalue of 1.0 and higher were used in the study. The following two criteria served as guidelines to label the individual factors: Each identified factor had to explain a relatively large proportion of the variance found in the study variables. Every identified factor had to be more or less independent of every other factor. Although a factor pattern was identified by the researchers, due to page limitations, only the broad factors were identified namely.

Factor 1: Customer service; Factor 2: Management policies; Factor 3: Operational functions; Factor 4: Capability to perform; and Factor 5: Organisational citizenship.

The five identified factors accounted for $54.9 \%$ of the total variance of the staff satisfaction evaluation (compared to $54 \%$ of the previous study done in 2004 where four factors were identified). The factor structure of the two studies correlated significantly. However, only the 2007 study will be used as base for the discussion. Determining the levels of satisfaction of the staff will thus provide users of the information with a fairly reliable framework on which to base intervention strategies.

The findings of the empirical study are consequently discussed.

\section{FINDINGS OF THE STUDY}

In the main findings of the study the medical staff and the nursing staff's evaluations were compared with regard to each of the five individual groupings as identified in the previous section.

According to Table 1, the overall highest score in this category was recorded by the nursing staff on personal appearance. Sufficient training to render a competent service was rated lowest in terms of satisfaction. Medical staff similarly rated personal appearance highest. No significant differences were measured between the sample groups. Medical staff's ability to keep promises made to patients was rated as least satisfactory. Significant differences between the two groups were measured in terms of variables 35,37 and 38 .

Over $80 \%$ of the respondents rated their level of satisfaction on personal appearance between good and excellent. 
Table 1: Customer service (Average mean 3.73)

\begin{tabular}{|c|c|c|c|c|c|c|}
\hline & & $\begin{array}{c}\text { Mean } \\
\text { Medical }\end{array}$ & SD & $\begin{array}{l}\text { Mean } \\
\text { Nursing }\end{array}$ & SD & $\begin{array}{c}\text { Mean } \\
\text { Difference }\end{array}$ \\
\hline Q36 & $\begin{array}{l}\text { How would you rate your personal } \\
\text { appearance? }\end{array}$ & $\begin{array}{c}3.96 \\
1\end{array}$ & 0.92 & $\begin{array}{c}4.15 \\
1\end{array}$ & 0.98 & -0.19 \\
\hline Q35 & $\begin{array}{l}\text { How do you rate your level of courtesy } \\
\text { towards the people you interact with in } \\
\text { your work environment? }\end{array}$ & $\begin{array}{c}3.71 \\
2\end{array}$ & 1.04 & $\begin{array}{c}3.85 \\
2\end{array}$ & 0.98 & $\underset{* *}{-0.14}$ \\
\hline Q37 & $\begin{array}{l}\text { How would you rate your ability to solve } \\
\text { problems the first time? }\end{array}$ & $\begin{array}{c}3.58 \\
3\end{array}$ & 1.05 & $\begin{array}{c}3.77 \\
5\end{array}$ & 0.96 & -0.19 \\
\hline Q38 & $\begin{array}{l}\text { How would you rate your ability to keep } \\
\text { promises made to patients? }\end{array}$ & $\begin{array}{c}3.49 \\
7\end{array}$ & 1.00 & $\begin{array}{c}3.83 \\
4\end{array}$ & 1.04 & $\underset{* *}{-0.34}$ \\
\hline Q34 & $\begin{array}{l}\text { How do you rate the individual attention } \\
\text { you provide to the people you interact } \\
\text { with in your work environment? }\end{array}$ & $\begin{array}{c}3.58 \\
3\end{array}$ & 1.02 & $\begin{array}{c}3.76 \\
6\end{array}$ & 0.93 & -0.18 \\
\hline Q33 & $\begin{array}{l}\text { How do you rate your own level of } \\
\text { knowledge of the services you provide? }\end{array}$ & $\begin{array}{c}3.52 \\
6\end{array}$ & 1.05 & $\begin{array}{c}3.85 \\
2\end{array}$ & 0.98 & -0.33 \\
\hline Q20 & $\begin{array}{l}\text { Are you sufficiently trained to render a } \\
\text { competent service? }\end{array}$ & $\begin{array}{c}3.55 \\
5\end{array}$ & 1.13 & $\begin{array}{c}3.72 \\
7\end{array}$ & 1.07 & -0.17 \\
\hline
\end{tabular}

${ }^{\star \star}=$ Significant differences on a $95 \%$ level of significance $p<0.05$ between groups

Rankings are indicated below the means

Table 2: Management policies (Average mean 2.54)

\begin{tabular}{|c|c|c|c|c|c|c|}
\hline & & $\begin{array}{l}\text { Mean } \\
\text { Medical }\end{array}$ & SD & $\begin{array}{l}\text { Mean } \\
\text { Nurses }\end{array}$ & SD & $\begin{array}{c}\text { Mean } \\
\text { Difference }\end{array}$ \\
\hline Q15 & $\begin{array}{l}\text { How do you rate Labour relations } \\
\text { management in the hospital? }\end{array}$ & $\begin{array}{l}2.36 \\
5\end{array}$ & 1.06 & $\begin{array}{c}2.67 \\
4\end{array}$ & 1.10 & $\underset{* *}{-0.31}$ \\
\hline Q8 & $\begin{array}{l}\text { How clear are the goals/ objectives of the } \\
\text { hospital? }\end{array}$ & $\begin{array}{c}2.82 \\
1\end{array}$ & 1.03 & $\begin{array}{c}3.07 \\
1\end{array}$ & 1.13 & -0.25 \\
\hline Q14 & $\begin{array}{l}\text { How do you rate personnel } \\
\text { management? }\end{array}$ & $\begin{array}{c}2.43 \\
3\end{array}$ & 1.10 & $\begin{array}{c}2.62 \\
6\end{array}$ & 1.10 & -0.19 \\
\hline Q18 & $\begin{array}{l}\text { How do you rate the overall management } \\
\text { of the Provincial Health Department? }\end{array}$ & $\begin{array}{c}2.19 \\
7\end{array}$ & 0.97 & $\begin{array}{c}2.49 \\
8\end{array}$ & 1.16 & -0.3 \\
\hline Q16 & $\begin{array}{l}\text { How do you rate overall hospital } \\
\text { management? }\end{array}$ & $\begin{array}{c}2.38 \\
4\end{array}$ & 1.10 & $\begin{array}{c}2.78 \\
3\end{array}$ & 1.17 & $\begin{array}{c}-0.4 \\
\star *\end{array}$ \\
\hline Q19 & $\begin{array}{l}\text { How do you rate the channels of } \\
\text { communication from top management to } \\
\text { your level? }\end{array}$ & $\begin{array}{c}2.14 \\
8\end{array}$ & 1.12 & $\begin{array}{c}2.63 \\
5\end{array}$ & 1.18 & $\begin{array}{c}-0.49 \\
* *\end{array}$ \\
\hline Q13 & $\begin{array}{l}\text { How do you rate the usefulness of } \\
\text { sectional/floor meetings? }\end{array}$ & $\begin{array}{c}2.80 \\
2\end{array}$ & 1.18 & $\begin{array}{c}2.81 \\
2\end{array}$ & 1.23 & -0.01 \\
\hline Q32 & $\begin{array}{l}\text { How do you rate the loyalty of the } \\
\text { Provincial Health Department towards its } \\
\text { employees? }\end{array}$ & $\begin{array}{c}2.27 \\
6\end{array}$ & 1.00 & $\begin{array}{c}2.52 \\
7\end{array}$ & 1.21 & -0.25 \\
\hline
\end{tabular}

${ }^{\star *}=$ Significant differences on a $95 \%$ level of significance $p<0.05$ between groups

Rankings are indicated below the means

The highest score in the management policy category (Table 2) was recorded by the nursing staff on clarity of the goals/objectives of the hospital, while the lowest score was recorded on the loyalty of the Provincial Health Department towards its employees. Medical staff members also evaluated the clarity of the goals/objectives of the hospital as being the highest while the lines of communication from top management to their level were evaluated as least satisfactory. Significant differences were measured in terms of variables $5,16,19$ and 32 . 
Overall staff members rated the clarity of the goals/ objectives of the hospital highest (33 percent evaluated it as moderate while $35 \%$ of the respondents rated it as above moderate). However the overall management of the Provincial Health Department was evaluated as lowest (28\% moderate and only $15 \%$ above moderate).

The variable in the capability to perform category (Table 3) that was rated highest (by nursing staff) was their ability to render a competent service while the competency of their direct supervisor was rated lowest in this category (although fairly high). Medical staff rated the competence of their direct supervisor highest while their ability to understand the goals of their department was rated least satisfactory. Significant differences were measured in terms of variable 9.

Overall the variable that was rated highest was the staff members' ability to render a competent service (66\% rated it more than moderate), while the rest of the variables in the category were also rated fairly satisfactory (between $54 \%$ and $57 \%$ rated it above moderate).

Table 3: Capability to perform (Average mean 3.502)

\begin{tabular}{|c|l|c|c|c|c|c|}
\hline & & $\begin{array}{c}\text { Mean } \\
\text { Medical }\end{array}$ & SD & $\begin{array}{c}\text { Mean } \\
\text { Nurses }\end{array}$ & SD & $\begin{array}{c}\text { Mean } \\
\text { Difference }\end{array}$ \\
\hline 9 & $\begin{array}{l}\text { How well do you understand the } \\
\text { goals of your department? }\end{array}$ & $\begin{array}{c}3.35 \\
4\end{array}$ & 1.16 & $\begin{array}{c}3.43 \\
3\end{array}$ & 1.11 & $\begin{array}{c}-0.08 \\
* *\end{array}$ \\
\hline 10 & $\begin{array}{l}\text { How do you rate your ability to } \\
\text { render a competent service? }\end{array}$ & $\begin{array}{c}3.41 \\
3\end{array}$ & 1.14 & $\begin{array}{c}3.86 \\
1\end{array}$ & 1.07 & -0.45 \\
\hline 11 & $\begin{array}{l}\text { How do you rate your colleagues' } \\
\text { commitment to their work? }\end{array}$ & $\begin{array}{c}3.51 \\
2\end{array}$ & 1.11 & $\begin{array}{c}3.48 \\
2\end{array}$ & 1.12 & 0.03 \\
\hline 12 & $\begin{array}{l}\text { How do you rate the competence } \\
\text { of your direct supervisor? }\end{array}$ & $\begin{array}{c}3.63 \\
1\end{array}$ & 1.23 & $\begin{array}{c}3.35 \\
4\end{array}$ & 1.23 & 0.28 \\
\hline
\end{tabular}

** Significant differences on a $95 \%$ level of significance $p<0.05$ between groups

Rankings are indicated below the means

Table 4: Operational functions (Average mean 2.96)

\begin{tabular}{|c|c|c|c|c|c|c|}
\hline & & $\begin{array}{l}\text { Mean } \\
\text { Medical }\end{array}$ & SD & $\begin{array}{l}\text { Mean } \\
\text { Nurses }\end{array}$ & SD & $\begin{array}{l}\text { Mean } \\
\text { Difference }\end{array}$ \\
\hline Q22 & $\begin{array}{l}\text { How well do you cope with your } \\
\text { workload? }\end{array}$ & $\begin{array}{c}3.04 \\
4\end{array}$ & 1.05 & $\begin{array}{c}3.08 \\
4\end{array}$ & 1.16 & -0.04 \\
\hline Q25 & $\begin{array}{l}\text { How do you rate the staff facilities } \\
\text { in your section? }\end{array}$ & $\begin{array}{c}2.71 \\
6\end{array}$ & 1.23 & $\begin{array}{c}2.81 \\
5\end{array}$ & 1.22 & -0.1 \\
\hline Q28 & $\begin{array}{l}\text { How do you rate occupational } \\
\text { health and safety in your work } \\
\text { environment? }\end{array}$ & $\begin{array}{c}2.85 \\
5\end{array}$ & 1.02 & $\begin{array}{c}3.10 \\
3\end{array}$ & 1.07 & -0.25 \\
\hline Q23 & $\begin{array}{l}\text { How do you rate race relations in } \\
\text { the hospital? }\end{array}$ & $\begin{array}{c}3.05 \\
3\end{array}$ & 1.11 & $\begin{array}{c}2.78 \\
6\end{array}$ & 0.98 & 0.27 \\
\hline Q24 & $\begin{array}{l}\text { How do you rate the patient care } \\
\text { facilities in your section? }\end{array}$ & $\begin{array}{c}3.36 \\
1\end{array}$ & 1.09 & $\begin{array}{c}3.31 \\
2\end{array}$ & 1.17 & 0.32 \\
\hline Q26 & $\begin{array}{l}\text { How do you rate the parking } \\
\text { facilities for your section? }\end{array}$ & $\begin{array}{c}2.53 \\
7\end{array}$ & 1.43 & $\begin{array}{c}2.17 \\
7\end{array}$ & 1.22 & 0.36 \\
\hline Q27 & $\begin{array}{l}\text { How do you rate the equipment in } \\
\text { your section? }\end{array}$ & $\begin{array}{c}3.29 \\
2\end{array}$ & 1.22 & $\begin{array}{c}3.42 \\
1\end{array}$ & 1.06 & -0.13 \\
\hline
\end{tabular}

${ }^{\star \star}=$ Significant differences on a $95 \%$ level of significance $p<0.05$ between groups

Rankings are indicated below the means

In the operational section (Table 4), the equipment in their section was rated most satisfactory by the nursing staff, whilst they rated the parking facilities least satisfactory. Medical staff rated the patient care 
facilities in their section highest while the parking facilities were rated least satisfactory. Significant differences were measured in terms of variable 23.

Overall the staff members rated the patient care facilities most satisfactory in this category (more than $50 \%$ of the respondents rated it better than moderate), followed by the equipment in their respective sections (more than $48 \%$ rated it better than moderate).

Table 5: Organisational citizenship (Average mean 3.11)

\begin{tabular}{|c|c|c|c|c|c|c|}
\hline & & $\begin{array}{l}\text { Mean } \\
\text { Medical }\end{array}$ & SD & $\begin{array}{l}\text { Mean } \\
\text { Nurses }\end{array}$ & SD & $\begin{array}{l}\text { Mean } \\
\text { Difference }\end{array}$ \\
\hline 17 & $\begin{array}{l}\text { How would you rate your influence on } \\
\text { hospital policy? }\end{array}$ & $\begin{array}{c}2.09 \\
3\end{array}$ & 0.99 & $\begin{array}{c}2.83 \\
2\end{array}$ & 1.07 & $\underset{* *}{-0.74}$ \\
\hline 30 & $\begin{array}{l}\text { How would you rate your own loyalty } \\
\text { towards the hospital? }\end{array}$ & $\begin{array}{c}3.45 \\
1\end{array}$ & 1.08 & $\begin{array}{c}3.90 \\
1\end{array}$ & 1.13 & $-\underset{* *}{-0.45}$ \\
\hline 31 & $\begin{array}{lll}\text { How would you rate your } & \text { loyalty } \\
\text { towards } & \text { Provincial } & \text { Health } \\
\text { Department? } & & \end{array}$ & $\begin{array}{c}2.86 \\
2\end{array}$ & 1.12 & $\begin{array}{c}3.56 \\
3\end{array}$ & 1.21 & -0.70 \\
\hline
\end{tabular}

${ }^{\star *}=$ Significant differences on a $95 \%$ level of significance $p<0.05$ between groups Rankings are indicated below the means

With regard to the organisational citizenship category (Table 5) of the staff, similar patterns were evident in both sample groups. Nurses' loyalty toward the hospital measured highest in this category while their loyalty towards the provincial health department was rated lowest. Medical staff rated their own loyalty towards the hospital highest. Significant differences were measured for variables 17 and 30 .

Overall staff members rated their own loyalty towards the hospital as most satisfactory $(62 \%$ of the respondents rated it higher than moderate, while overall they rated their influence on hospital policy least satisfactory $(21 \%$ rate it more than moderate).

\section{Table 6:Variables that explains satisfaction best}

\begin{tabular}{l|l|l|l|l|}
\hline Item & Description & Factors & Medical & Nurses \\
\hline 8 & How clear are the goalslobjectives of the hospital? & MP & 2.82 & 3.07 \\
\hline 9 & $\begin{array}{l}\text { How well do you understand the goals of your } \\
\text { department? }\end{array}$ & CTP & 3.35 & 3.43 \\
\hline 14 & How do you rate personnel management? & MP & 2.43 & 2.62 \\
\hline 16 & What is your rating of overall hospital management? & MP & 2.38 & 2.78 \\
\hline 18 & $\begin{array}{l}\text { How do you rate the overall management of } \\
\text { Provincial Health Department? }\end{array}$ & MP & 2.19 & 2.49 \\
\hline MP = Management policy & & \\
CTM = capabilities to perform \\
Scale: 1 = very poor 5 = excellent
\end{tabular}

Following the results of the regression analysis identified variables 8, 9, 14, 16 and 18 as the variables explaining satisfaction best amongst all variables used in the questionnaire.

\section{MANAGEMENT IMPLICATIONS}

The staff satisfaction variables that were evaluated in the study were reduced to five factors namely: Factor 1: Customer service; Factor 2: Management policies; Factor 3: Operational functions; Factor 4: Capability to perform; and Factor 5: Organisational citizenship. 
Based on the average mean scores, the factor that scored the highest overall by the sum of the two samples was factor 1: customer service. It is clear from the study that staff members tend to be more positive regarding their own personal contribution towards rendering customer service to their customers (patients).

The single factor that scored the lowest overall score was factor 2: management policy issues. It is evident that the management team do not perform their managerial duties efficiently (management in this sense does not only refer to the management of the particular hospital, but also includes management by the provincial health department). It is interesting to note that only $18 \%$ of the respondents were part of the management team of the hospital.

Based on the analysis that identified the variables that describe satisfaction best, it is clear that management should take immediate steps to address the following issues:

- The clarification of hospital goalslobjectives

- Understand of the goals of the respective departments

- Functioning of the personnel management

- Functioning of the overall hospital management

- Functioning of the overall Provincial Health Department.

All the abovementioned variables have an influence on the hospital employees' level of job satisfaction. Internal marketing, especially in its emphasis on customer awareness, asserts that to satisfy the customer's needs, the organisation should first satisfy the needs of its own staff. This applies specifically to health care organisations where a service is rendered (George \& Compton, 1985).

\section{CONCLUSION}

In conclusion it is imperative that internal needs within an organisation should be identified as employees are at the centre of service delivery. The way, in which management manages their staff, co-ordinating and integrating inter-functional activities, applying a marketing oriented approach and focussing on the capabilities of the employees should be regarded as key determinants in applying a successful internal marketing strategy. It is clear that management should address all these variables when preparing their management strategy. Provision should be made to address each of these variables individually and to commit them to assessing the influence of these variables on their subordinates. Furthermore these variables should be redressed through suitable actions.

\section{REFERENCES}

Ahmed PK \& Rafiq M. 2002. Internal marketing. Oxford: Butterworth-Heineman.

Bergh ZC \& Theron AL. 1999. Psychology in the work context. New York. Oxford Press.

Berry LL \& Parasuraman A. 1991. Marketing services. Competing through quality. New York: The free press.

Bunz UK \& Maes JD. 1998. Learning excellence: Southwest Airlines' approach. Managing Service Quality, 8(3):163-169.

Buch E. 2000. The health sector strategic framework: a review: South Africa Health Review. Durban, SA: Health Systems Trust.

Chahill DJ. 1996. Internal marketing: your company's next stage of growth. 
Carr-Hill RA. 1992. The measurement of patient satisfaction. Journal of Public Health Medicine. 14:236249.

Caruana A \& Calleya P. 1998. The effect of internal marketing on organisational commitment among retail bank managers. International Journal of Bank Marketing, 16(3):108-116.

Cravens DW \& Piercy NF. 2003. Strategic Marketing. New York: McGraw-Hill/Irwin.

Czaplewski AJ, Ferguson JM \& Milliman JF. 2001. Southwest Airlines: how internal marketing pilots success. Journal of Marketing Management, 14-17

Costello MA. 2001. Hospital staff satisfaction translates to patient satisfaction. AHA News, 37(46):8.

De Jager JW \& Swanepoel S. 2005. Staff satisfaction in health care. Unpublished report.

De Nobile JJ \& McCormick J. 2008. Job satisfaction of Catholic primary school staff: a study of biographical differences. International Journal of Education Management, 22:135-150.

Donabedian A. 1988. The quality of care. How can it be assessed? JAMA 1988, 260(12):1745-1748.

Du Plessis PJ, Jooste CJ \& Strydom JW. 2005. Applied strategic marketing. Sandton: Heinemann Publishers (Pty) Ltd.

Dyck D. 1996. Gap analysis of health services. Client satisfaction surveys. AAOHN Journal, 44(11): 541549.

Friedenberg RM. 1997. The next medical revolution should be quality. Radiology, 204(1):31a-34A.

George WR \& Compton F. 1985. How to initiate a marketing perspective in health services. Journal of health care marketing, Winter 85(1):29-39.

Gibson JL, Ivancevich JM, Donelly JH \& Konopaske R. 2003. Organizations: behavior, structure, processes. Boston: McGraw-Hill, Irwin.

Gounaris S. 2006. The notion of internal market orientation and employee job satisfaction: some preliminary evidence. Journal of Service Marketing, 22(1):68-90.

Grönroos C. 1978. A service - oriented approach to the marketing of services. European Journal of Marketing, 12(8):588 - 601 .

Grönroos C. 1994. From marketing mix to relationship marketing. Towards a paradigm shift in marketing. Journal of Management Decision, 32(2):4-20.

Hill FM \& McCrory ML. 1997. An attempt to measure service quality at a Belfast maternity hospital: some methodological issues and some results. Total Quality Management, 8(5):229-243.

Hellriegel D, Slocum JW \& Woodman RW. 2001. Organizational behavior. Ohio: South Western.

Joseph WB. 1996. Internal marketing builds service quality. Journal of Health Care Marketing, 96(16):54.

Kollberg B, Dahlgaard JJ \& Brehner PO. 2007. Measuring lean initiatives in health care services: issues and findings. International Journal of Productivity and Performance Management. 56(1):7-24.

Kotler P \& Clarke RN. 1987. Marketing for health care organisations. Englewood Cliffs: Prentice Hall. 
Kotler P \& Andreasen AR. 1996. Strategic marketing for nonprofit organizations. $3^{\text {rd }}$ ed. Prentice Hall: Englewood Cliffs.

Kotler P \& Armstrong G. 1993. Marketing. $3^{\text {rd }}$ ed. London: Prentice Hall.

Krueger P, Brazil K, Lohfeld LHG, Lewis D \& Tjam E. 2002. Organization specific predictors of job satisfaction.

McCormick EJ \& Ilgen D. 1992. Industrial and organizational psychology. London: Erwin Hyman Ltd.

Muchinsky PM. 1993. Psychology applied to work. California: Brooks Cole.

Nel PS, Van Dyk PS, Haasbroek GD, Schultz HB, Sono T \& Werner A. 2004. Human resources management. Cape Town: Oxford University Press.

Nelson DL \& Quick JC. 2003. Organizational Behavior: Foundations, realities and challenges. Ohio: Thomson South Western.

Organ DW. 1988. Organizational Citizenship Behavior: The Good Soldier Syndrome. Toronto: Lexington Books.

Robbins SP. 2003. Organizational behavior. Upper Saddle, New Jersey: Prentice-Hall.

Robbins SP \& Coultar MC. 1999. Management. Upper Saddle, New Jersey: Prentice-Hall.

Robbins SP \& Judge TA. 2007. Organizational behavior. Upper Saddle, New Jersey: Prentice-Hall.

Sajid MS \& Baig MK. 2007. Quality of care: an absolute necessity for public satisfaction. International Journal of Health Care Quality Assurance, 20(6):545-548.

Schultz DP \& Schultz SE. 1994. Psychology and work today. New York. Macmillan.

Solomon MR \& Stuart EW. 2003. Marketing: Real People, Real Choices. New Jersey:Pearson Education.

Simonet D. 2005. Patient satisfaction under managed care. International Journal of Health Care Quality Assurance, 18(6):424-440.

Strydom J. 2004. Introduction to marketing. Cape Town: Juta and Co Ltd.

Van Dyne L, Cummings LL \& Dienesch RM. 1994. Organizational citizenship behavior: construct redefinition, measurement and validation. Academy of Management Journal, 37.

Zeffane R \& Al Zarooni HAM. 2008. The influence of empowerment, commitment, job satisfaction and trust on perceived performance. International Journal of Business Excellence, 1(2). 